\title{
P J Hoedemaker, teoloog en kerkman
}

\author{
D J C van Wyk \\ Universiteit van Pretoria
}

\begin{abstract}
P J Hoedemaker, theologian and man of God

This article highlights aspects of $\mathbf{P} \mathbf{J}$ Hoedemaker's theology: It also deals with his academic work at the Vrije Universiteit, his views on the Scriptures and on historical criticism as well as his philosophical approach, concepts and formulation. Attention is also paid to his views on education, religious instruction and the university. His views on the state and his conflict with Doctor Kuyper on the subject are also dealt with.
\end{abstract}

\section{INLEIDING}

In 'n vorige artikel in die Hervormde Teologiese Studies (Van Wyk 1990:497-512) is gehandel oor die lewe en werk van dr P J Hoedemaker, predikant van die Nederlandse Hervormde Kerk aan die einde van die negentiende en die begin van die twintigste eeu. In dié artikel is veral gehandel oor die kontrovers tussen Abraham Kuyper en Hoedemaker na aanleiding van hulle verskil in opvatting oor die kerk. Dié kontrovers lei tot Hoedemaker se bedanking as hoogleraar aan die Vrije Universiteit. Maar met sy weiering om met die Doleansie saam te gaan, het Hoedemaker ook die gang van die Nederlandse kerkgeskiedenis beslissend beïnvloed.

Daarom bly Hoedemaker 'n belangrike figuur in die kerkgeskiedenis. Sy teologiese verantwoording oor waarom hy prinsipieel nie met kerkskeuring kan saamgaan nie, is steeds uiters relevant, so ook sy passie vir die eenheid en heelheid van die kerk en die Nederlandse volk.

Maar Hoedemaker was nie net kerkman en volksman nie; hy was ook 'n skrander, wydbelese teoloog, 'n oorspronklike, skerpsinnige denker en skrywer. Sy veelsydigheid is indrukwekkend. Daar is bykans nie 'n terrein van die destydse teologiese, kerklike en volkslewe waarop hy hom nie begeef het nie. Daar is bykans geen van die vername kerklike en teologiese rigtings van sy tyd met wie hy nie op 'n stadium 
in ernstige gesprek of diskussie was nie; 'n kompromislose mens wat niemand nagepraat het nie.

In hierdie artikel word nou verder stilgestaan by die teologiese werk van Hoedemaker wat nie in die vorige uitgawe van HTS aan die beurt kon kom nie. Daar word gekyk na sy Skrifbeskouing, sy akademiese werk aan die Vrije Universiteit, sy staatsbeskouing en sy siening oor onderwys en die godsdienstige opvoeding van die jeug.

Soos in die vorige artikel vermeld, is ook hierdie bydrae nie bedoel as studie oor Hoedemaker aan die hand van primêre bronne nie. Dit is slegs 'n poging om die relevansie van die lewe en werk van $\mathbf{P} \mathbf{J}$ Hoedemaker vir ons tyd weer onder lesers van die HTS, veral in Suid-Afrika, se aandag te bring aan die hand van resente publikasies tydens 'n Hoedemaker-herdenking in 1989, een honderd en vyftig jaar na Hoedemaker se geboorte.

\section{AS AKADEMIKUS AAN DIE VRUE UNIVERSITEIT}

Op 30 April 1880 word Hoedemaker deur die direkteure van die Vereniging vir Hoër Onderwys op Gereformeerde grondslag benoem tot hoogleraar in filosofiese vakke. Saam met hom word F L Rutgers benoem vir die historiese vakke en A Kuyper vir die dogmatiese vakke. Omdat Kuyper vroeër in De Heraut betoog het 'dat de genade particulier is', was daar van die kant van sommige kuratore aanvanklik beswaar teen sy benoeming. Dit kon eers deurgaan nadat hy teenoor die kuratore beloof en onderneem het om ook die verbondsteologie te leer (Abma \& De Bruijn 1989:50).

Net op hierdie punt was daar dus al klaar 'n belangrike klemverskil tussen Kuyper en Hoedemaker. Dat die verbond 'n belangrike rol gespeel het in Hoedemaker se beskouing oor die kerk, was algemeen bekend. Op skimpe dat niemand wat nie presies soos Kuyper dink aan die Vrije Universiteit aangestel sou word nie, het Kuyper juis gereageer met die argument dat hy self vanweë sy noue betrokkenheid by die oprigting van die Vrije Universiteit 'n belangrike aandeel in Hoedemaker se benoeming gehad het terwyl Hoedemaker se teologie op belangrike punte van syne verskil het.

Dit is ook een van die belangrikste redes waarom Hoedemaker self uit die staanspoor getwyfel het of hy die benoeming moet aanvaar. In 'n skrywe aan Rutgers laat hy hom oor sy verhouding met Kuyper so uit: 'Hij is mijn betere, maar ik ben een ander...Er is in mijn hart niets dan trouwe, hartelijke liefde voor hem, maar, ik kom steeds tot andere conclusies...' (Abma \& De Bruijn 1989:51).

Hoedemaker het gevoel dat hy, deur sy benoeming onder andere uit die hand van Kuyper te aanvaar, gekompromitteer is om die vrede te bewaar. Hy oorkom eg- 
ter sy aarseling en aanvaar die benoeming met die uitgesproke hoop om te eniger tyd weer tot die kansel toegelaat te word.

Tydens die amptelike opening van die Vrije Universiteit hou Hoedemaker, op voorstel van Kuyper, die wydingsrede. Hy knoop daarin aan by die gedeelte in 1 Samuel 13:19-22 en veral die woorde: 'Daar was geen smid in die hele Israel nie....' Dit was geen gewone preek nie, maar 'n wetenskaplike besinning oor wat die Vrije Universiteit wou wees. In sy rede bestry hy die voorwaardes vir 'n bondgenootskap tussen wetenskap en modernistiese teologie. Die Vrije Universiteit is gebore uit die behoefte aan voorgangers wat geleer het om die belydenis van die kerk nie te bestry, te ondermyn of af te water nie; maar terselfdertyd net so sterk uit die oortuiging dat Jesus Christus koning is, ook op die gebied van die wetenskap. Daarom was dit geen waagstuk nie, maar heilige roeping om nie 'n kweekskool nie, maar 'n universiteit op te rig. Die Vrije Universiteit se taak was om in hierdie geding met die moderne wetenskap oor die koningskap van Christus, die wapens vir die kerk en die teologie te verskaf.

Hoedemaker se wydingsrede, gehou in die Nieuwe Kerk te Amsterdam, toon duidelik dat die totstandkoming van die Vrije Universiteit op dié oomblik vir hom die vervulling van 'n heilige ideaal was. Die beginsel wat vir hom op die spel was, was die koningskap van Christus. 'Hierover toch loopt het geding tusschen ons en die moderne wetenschap' (Scheers 1939:59). Die vraag is of Christus deur sy Woord oor elke lewenskring heers; geen dualisme dus tussen geloof en wetenskap nie. Aan die Vrije Universiteit moet die Gereformeerde beginsel tot gelding kom: Alles en almal moet aan God die eer gee. Alleen as die wetenskap reken met God, is dit werklik wetenskap.

Maar na hierdie wapenkreet, sê Hoedemaker vervolgens in sy wydingsrede, moet die bewapening volg. Maar die wapens is, na analogie van die teksverhaal, in die hande van die vyand: woord, lied, pers, wetenskap, wetgewing, openbare mening. Die Vrije Universiteit se taak is om opnuut die wapens vir die stryd te smee. Alleen só sal Christus die eer kry en die Nederlandse volk gered word. Die Vrije Universiteit is 'n deur van hoop vir die teologie, die wetenskap as geheel, kerk en volk. Hierdie uitspraak van Hoedemaker, sê Scheers (1939:60), was sy mees Kuyperiaanse. En oor dié aspek was daar ook inderdaad tussen Kuyper en Hoedemaker geen wesenlike verskil nie. Sy verskil met Kuyper kom eers na vore aan die einde van sy rede as hy na die verbond verwys as grondslag van die volkslewe. Dit is ook Gereformeerd, sê hy, om die individue nie as enkelinge nie, maar as deel van die groot samehangende lewende geheel van die Nederlandse volk te sien. Reeds hier gaan dit vir Hoedemaker nie om 'n bepaalde volksdeel nie. Die Vrije Universiteit moet die heil van heel die kerk en heel die volk dien. 


\section{P J Hoedemaker}

Hoedemaker se benoeming as hoogleraar in die filosofiese vakke het beteken dat hy onderrig op die volgende terreine moes verskaf: natuurlike teologie, geskiedenis van die godsdienste, die Christelike volkekunde en kennis van die Mohammedanisme. Ná'n jaar besluit Kuyper om self die doseerwerk in die natuurlike godgeleerdheid oor te neem. Dit gebeur onder ernstige protes van die kant van Hoedemaker.

In sy aanvanklike doseerwerk gee Hoedemaker besondere aandag aan die etiek. Hy konstateer dat die teoloë van sy tyd in hulle etiek gekonformeer het aan die deur Kant beïnvloede sedelikheidsideaal. Self wil hy van die begin af die geloofselement laat meespreek deur as volstrekte beginsel van etiek te aanvaar: Die mens is na die beeld van God gemaak. Hy wys alle sisteme wat op remonstrantse wyse van die mens as subjek uitgaan, af. Hy wys die etiese rigting tereg, omdat hulle in voetspoor van Schleiermacher se subjektivisme die dogmatiek laat opkom uit die etiek, die godsdienstige lewe van die mens. Ook van $\mathbf{J} \mathbf{J}$ van Oosterzee distansieer hy hom omdat Van Oosterzee volgens hom te veel 'mens' in sy dogmatiek toelaat. Die etiek, so poneer Hoedemaker, het 'n teologiese karakter.

Toe daar teen 1882 nog nie geslaag kon word om 'n geskikte bekleër vir die hoogleraarskap in Praktiese Teologie te vind nie, bied Hoedemaker vanweë 'n bepaalde dringendheid van die saak aan om dit oor te neem in ruil vir die filosofiese vakke en op voorwaarde dat hy die onderrig in die etiek kan behou. Hy het deurgaans geoordeel dat die etiek meer tot die praktiese vakke behoort. Daar is ook geoordeel dat die leerstoel in die filosofiese vakke makliker gevul sou kon word. In 1882 word Hoedemaker ook rektor van die teologiese fakulteit.

Ongeag sy aandrang om die vak etiek te behou, was Hoedemaker (in hierdie jare altans) in lynregte botsing met die etiese rigting van sy tyd. Vir die etiese teoloë gaan dit immers nie in die eerste plek om die eer van God en die reg van Christus nie, maar om die vraag: Hoe gaan dit met die mens, die dominee, die jongmens, die evangelisasie, die filantropie? Vir 'n Gereformeerde gaan dit egter altyd daarom om aan Christus die plek te gee wat Hom toekom en daarom om dié kring van waar hy die volkslewe in al sy fases en vorme kan beheers: wetenskap, skool, universiteit.

Intussen is daar baie tekens van 'n groeiende konflik tussen Hoedemaker en Kuyper. Afgesien van hulle teologiese verskille het hulle persoonlikhede gebots. Hoedemaker het by Kuyper hooghartigheid en meermale 'n gebrek aan samewerking gevind. Gedurende twee maande in $1883 \mathrm{kan}$ hy nie slaag om 'n senaatsvergadering byeen te kry om smeulende sake te probeer besleg nie. Kuyper was daarvoor te besig, waarskynlik met kerklike sake. As Kuyper 'n keer probeer om Hoedemaker se karakter te skets, herken Hoedemaker homself nie daarin nie. Aan Kuyper skryf hy op sy beurt: 'Gij zijt apodiktisch, maar gij zijt dit op de beminnelijk- 
ste wijze en neemt daarbij zulk een verhevene stelling in, dat het geraden is te zwijgen' (Abma \& De Bruijn 1989:62).

Ook oor die kerklike kwessie was daar groeiende spanning. Hoedemaker het gehoop dat Kuyper onderskeid sou maak tussen sy akademiese posisie aan die universiteit en sy kerklike situasie op die Amsterdamse kerkraad. In Kuyper se argumentering rondom die vraag of die Hervormde sinode ook kwekelinge van die Vrije Universiteit tot die proponentseksamen kon toelaat, hoor Hoedemaker klanke wat hom diep verontrus. Oor Kuyper se opvatting ten opsigte van die kerkverband skryf hy dat die kerke nie saamkom nie - hulle behoort saam. Kuyper se opvatting oor die kerkverband was volgens hom nie in lyn met dié van die Gereformeerde vaders nie, maar met dié van Vinet, De Labadie en Schleiermacher.

Maar intussen grawe Hoedemaker homself so goed moontlik in sy nuwe akademiese werkopdrag in. Met die benaming Praktiese Teologie was hy nooit gelukkig nie. Hy sou liewer voorkeur gee aan Practicale Godgeleerdheid. In werklikheid was dit 'n verset teen Schleiermacher. Teen laasgenoemde se omskrywing van die Praktiese Teologie as 'die Technik zur Erhaltung und Vervolkommnung der Kirche' (Abma \& De Bruijn 1989:64), wou hy hom so duidelik as moontlik afgrens. Dit het volgens hom van die kerk 'n vereniging van mense gemaak wat deur die dryfkrag van hulle godsdienstige belewing saamgebring is. Hy sien in die nuwere teologie 'n subjektivisme waarin die mens, soos by die Arminianisme, verhef word. Self gaan Hoedemaker uit van die kerk as kerk van die Here, die liggaam van Jesus Christus, volgens die Heidelbergse Kategismus, Sondag 21.

Op diakonale gebied wil hy loskom van diakonale wette en privaat liefdadigheid. Hy wil kom tot 'n omvattende diakonaat wat tot eer van die Heer van die kerk kan wees. Die sendingwerk van verenigings eis hy vir die kerk op.

Die jare 1883-1884 word in die lewe van Hoedemaker oorheers deur sy stryd op kerklike terrein met Kuyper en sy geesgenote, veral rondom die geval Houtzagers (Van Wyk 1990:505). Agterna beskou, kry 'n mens tog die indruk dat Hoedemaker, hoewel hy homself sonder enige reserwe aan sy akademiese werk gegee het, meer in die kerklike problematiek van sy tyd geïnteresseerd en betrokke was. Waarom het hy sewe jaar aan die Vrije Universiteit uitgehou? Waarskynlik omdat hy op naiewe wyse gehoop het dat die Vrije Universiteit sou kon bewerk en bereik wat tot dusver langs geen kerklike weg bereik kon word nie: die so begeerde kerkherstel en bevryding uit die sinodale knelling van 1816 (Abma \& De Bruijn 1989:70).

Dat Hoedemaker hom inderdaad sonder reserwe aan sy akademiese opdrag gewy het, blyk nie net uit sy omvattende publikasies nie, maar ook uit 'n oorsig oor wat hy alles gedoseer het sedert sy benoeming in 1880. Naas die doseeropdrag in Praktiese Teologie met al die kwalifikasies daaraan verbonde, soos reeds vermeld, 
het hy tot met sy uittrede in 1887 ook die oorspronklike filosofiese vakke bly doseer omdat daar nooit 'n geslaagde benoeming in die opsig gemaak kon word nie. Daarbenewens moes hy van die begin tot die einde van sy akademiese loopbaan ook aan die voorbereidende studente lesings gee: vanaf Engelse taal- en letterkunde tot logika en geskiedenis van die wysbegeerte. Na die bedanking in September 1885 van $F$ W J Dilloo wat Ou Testament doseer het, kry hy as verdere opdrag ook gedeeltes uit die studie van die Ou Testament, onder andere Inleidingswetenskap waarin hy Wellhausen en Kuenen se rekonstruksie van Israel se geskiedenis behandel. Die ryke skat aan gegewens wat hy in sy lesings oor die Hebreeuse oudhede publiseer, blyk uit sy publikasie in 1885: Handboek voor het onderwijs in het Oude Testament.

Aan die einde van 1887 het Hoedemaker as gevolg van die groeiende kerklike konflik met Kuyper sy ontslag as hoogleraar aangevra. Besonderhede oor dié verloop van sake is reeds in 'n vorige uitgawe bespreek (Van Wyk 1990:503). Hoedemaker kon nie verder aanpas, toegee en vrede bewaar nie omdat hy oortuig geraak het dat Kuyper die Vrije Universiteit in diens van die Doleansie aangewend het. Dit het gebots teen alles wat Hoedemaker self vir die inrigting in vooruitsig gehad het. Sy uiteindelike uittrede het hy as ' $n$ bevryding uit 'n lamlendige posisie ervaar.

Gedurende sy jare aan die Vrije Universiteit het Hoedemaker tot volkome selfstandigheid gegroei. Hy het nie groot teologiese werke gepubliseer nie. Daarvoor was sy leeropdrag te wyd en sy kerklike betrokkenheid te intens. Maar hy het hom in dié jare, hoe moeisaam ook al, innerlik van Kuyper losgemaak. 'Kuyper is bezig mij te emanciperen', skryf hy in 1885 (Abma \& De Bruijn 1989:84). In wat hy gedurende dié jare wel publiseer, blyk daar 'n duidelike wending weg van Schleiermacher na Voetius toe.

Sy ontwikkeling tot selfstandigheid en sy losmaking van Kuyper blyk uit twee uitsprake wat hy in skrywes aan Kuyper maak. In 1884 skryf hy in spottende toon oor homself: 'God heeft mij, al lijd ik gedurig onder den invloed van mijne methodistisch-Amerikaansche zwevend-Utrechtsche, zoowel als mijn Fichtiaansche en Ethische periode en vorming, met voidoende verstand begaafd, om eene of andere kwestie te doordenken' (Abma \& De Bruijn 1989:83). En in 1887 skryf hy: ' Met al mijne zwakheden en niet het tiende part van uw gaven, neem ik aan u uit dat [Gods] woord te weerleggen' (in Abma \& De Bruijn 1989:83).

\section{HOEDEMAKER SE SKOLING IN DIE FILOSOFIE}

Dit is nodig om in enkele afsonderlike paragrawe die aandag te vestig op die feit dat Hoedemaker deeglik ingegrawe was in die wysbegeerte. Dit was van besondere invloed en betekenis in sy werk. 'Door zijn filosofie-studie was hij getraind om vanuit beginselen te denken en daarin de onrzaak van verkeerde ontwikkelingen te zoe- 
ken. Zijn pleidooi voor de terugkeer tot de beproefde beginselen der Vaderen hangt daarmee samen' (Balke 1989:2).

Hoedemaker het in 1867 magna cum laude aan sy Utrechtse Alma Mater gepromoveer met 'n godsdiens-wysgerige proefskrif getitel 'Het probleem der vrijheid en het theïstische Godsbegrip'.

Oor dié proefskrif skryf A Vos (Aḅma \& De Bruijn 1989:99):

Er zijn drie soorten boeken: boeken die je in een uur doorleest en uitleest, boeken waar je een dag voor nodig hebt, en boeken die je aandacht blijven opeisen. Proefschriften in de Nederlandse theologie van de negentiende eeuw vallen grotendeels in de eerste categorie. Als aan het eind van de morgen de creativiteit taant, kan men zich nog voor het middageten ontspannen door zo 'n boekje door te nemen. Maar met Hoedemakers proefschrift lukt dat niet. Later zou hij nog vele vloeiende publicaties in het licht geven, die zich door haar heldere en appellerende retoriek lichtvoetig en hartgrondig laten lezen. Maar zijn godsdienstwijsgerige dissertatie is boordevol gedachten zonder een omgevallen boekenkast te worden.

Uitgaande van de empirische werkelijkheid tracht Hoedemaker alsmaar door te denken om vanuit de integratie van speculatie en empirie dit dilemma te overwinnen en de transcendente grond van alles te ontdekken in zijn eigen werkelijkheid, zoals hij zich in en vanuit de gegeven empirische werkelijkheid verhult, openbaart en ook denkend laat vinden. Dat gebeurt in een uitermate gecompliceerd, rijk en overladen boek, dat midden in de negentiende eeuw zeer onnegentiende-eeuws is, een fascinerend product van een jonge man die werelden verbindt, als een filosofische atlas die geschoolde helderheid niet kan vinden. De latere Hoedemaker bleef voor vele tijdgenoten raadselachtig, de jonge is al een mysterie, als denker van een losbandige genialiteit.

So ingewikkeld as wat Hoedemaker se persoonlikheid en karakter was, so moeilik was en bly dit steeds vir sy tydgenote en latere navorsers om hom as kerkman en akademikus te tipeer en sy denke te omlyn. As kerkman was hy voortdurend besig om hom los te mak uit die inpalming deur groepe en rigtings. Hy het op kardinale punte van die etiese rigting van Gunning verskil, hy was allermins 'n neo-Calvinis, uit die konfessionele rigting en vereniging het hy hom losgeruk, hy was nie modern nie. Maar hy was ook nie konserwatief nie, want hy was voortdurend uit op die hernude formulering van die waarheid. Balke (1989:1) tipeer hom as negentiende- 
eeuse verteenwoordiger van die Nadere Reformasie. Maar ook daanit sou Hoedemaker hom waarskynlik losmaak.

Daar is reeds gewys op die uiteenlopende dissiplines wat hy aan die teologiese fakulteit hanteer het. En dan sy ongelooflike belesenheid in die filosofie:

Hele werelden paraderen in Hoedemakers belezenheid. Niet alleen de antieke filosofie, met zelfs de oude commentaren op Aristoteles als die van Simplicius, en met de handboeken van de grote Duitse filosofie-historici als Trendelenburg, Fischer, Zeller, en Ueberweg. Maar ook de Franse wereld is duidelijk aanwezig, niet alleen met Descartes, maar ook met Victor Cousin, Bartholmess, Secrétan en Maine de Biran.

Het is echter vooral de gestalte die de westerse filosofie in de zeventiende eeuw vanuit het werk van Descartes heeft gekregen, die het zoeken van Hoedemaker bepaalt: Descartes, Spinoza, Locke, Leibniz, Kant, Hegel, Fichte, Schelling en Schopenhauer zijn massief aanwezig. Hoewel zij van grote betekenis zijn voor de feitelijke voeding van het betoog, doordat de systematische waarheid langs lijnen van filosofiehistorische ontwikkeling wordt gezocht, blijkt toch een andere denkwereld de achtergrond te bepalen: het Engelstalige denken in zijn Amerikaanse, Engelse en Schotse vormen. Daar horen niet alleen Hume en Mill bij, maar ook Reid, Hamilton, Edwards en Emerson.

(Abma \& De Bruijn 1989:100)

Dit was hierdie wye belesenheid in die filosofie wat Hoedemaker, naas sy kennis van die Bybel en sy teologiese vermoëns, gehelp het om die ontsporing van teologie en kerk in sy tyd te definieer en terselfdertyd nie die oplossings van Kuyper te aksepteer nie.

Descartes, met sy uitgangspunt vir alle kennis in die subjek, beskou Hoedemaker nie net as die vader van die nuwere filosofie nie, maar ook as baanbreker van die nuwe teologie. Die Arminianisme, as teologie verwerp, word nou weer as filosofie aangebied en aanvaarbaar gevind. Descartes skei wat God verenig het: geloof en kennis, Heilige Skrif en menslike rede. Descartes se standpunt word nie net dié van die supranaturaliste nie, maar ook van manne soos Van Oosterzee, trouens van die teologie ná Schleiermacher. Descartes het vir sy filosofie maar 'n klein plekkie gevra, maar spoedig is die verhoudinge omgekeer en is die teologie van die gebied van die wetenskappe verdryf. Voetius was volgens Hoedemaker die doeltreffende teenvoeter vir Descartes. 


\section{HOEDEMAKER OOR DIE VERSTAAN EN UITLEG VAN DIE BYBEL}

Soos op ander terreine is dit ook op die terrein van die verstaan en uitleg van die Skrif moeilik om Hoedemaker se denke te volg. In baie opsigte sou 'n mens van hom kon praat as dialektiese denker en teoloog. Hy wou nooit iets anders wees as predikant in sy geliefde kerk, die Nederlandse Hervormde Kerk nie. Hy was 'n praktiese leser en bestudeerder van die Bybel wat sy enorme Skrifkennis graag wou rig en toespits op die kerklike praktyk. Soos aangetoon, kon hy ook tydens sy akademiese jare aan die universiteit nooit loskom van die kerklike praktyk nie.

Maar tog het daar altyd ook 'n sterk idealistiese trek in sy teologie gebly. Baie van sy opvattings, veral as dit by onderwys en staatkunde kom, was onprakties en verder vir die kerk onbruikbaar. Dat daar nogtans van sy teologiese denke tot diep in die twintigste eeu soveel invloed uitgegaan het, is ' $n$ aanduiding van die enorme krag en omvang van sy denke.

Wat sy teologiese insigte ten opsigte van die verstaan en uitleg van die Bybel betref, moet dadelik toegegee word dat baie daarvan vandag totaal verouder en agterhaal is. Selfs in baie konserwatiewe teologiese kringe kan dit nie sonder meer gehandhaaf en nagevolg word nie. Baie van die moderne insigte en metodes wat Hoedemaker so fel bestry het, is vandag algemeen aanvaar.

Tog bly dit prikkelend en bevrugtend om ook op hierdie terrein met sy teologie besig te wees. Daarby verteenwoordig Hoedemaker 'n pool in die beskouing oor die Skrif wat nooit in die kerk mag ontbreek nie. Daarmee staan die eer van God, die geloof van die kerk en die heil van die mens op die spel. 'n Studie van sy opvattings oor verstaan en uitleg van die Bybel is blywend relevant, veral vanweë sy enorme Bybelkennis waardeur hy in staat was om Skrifwoord met Skrifwoord te vergelyk, maar ook vanweë sy uitgebreide kennis van die filosofie van waaruit hy die herkoms van dwaalweë in sy eie tyd herken en beskryf het.

In Nederland, vir die grootste deel van die negentiende eeu, was daar 'n paar duidelike teologiese strominge herkenbaar: Verligting, Groninger Teologie, Afskeiding, Réveil, Modernisme, Etiese Teologie. Teen al dié rigtings het Hoedemaker hom verset.

Hy het hom egter veral fel verset teen die opvattings van die negentiende-eeuse Ou-Testamentiese Wetenskap en veral dié van die Duitser J Wellhausen, later gevolg deur die Nederlander, A Kuenen. Wellhausen se werk uit 1878, Prolegomena zur Geschichte Israëls, bevat 'n radikale rekonstruksie van die Ou Testament. Strydig met die oortuiging tot op dié tydstip, naamlik dat Moses die wet van God ontvang het en aan Israel deurgegee het, beweer Wellhausen dat die wetgewing 'n eindproduk in die geskiedenis van Israel was wat eers tydens die ballingskap tot sy huidige vorm gefinaliseer is. 
Vir Hoedemaker het dit nie gegaan om die Mosaïese oorsprong van die wet nie, maar om die Goddelike oorsprong van die Heilige Skrif. Dit gaan vir hom om iets anders en hoër as net die tyd waaruit bepaalde uitsprake in die Ou Testament geld. Volgens hom, skryf Hoedemaker aan 'n teenstander, gaan dit in die diskussie rondom die Skrifgesag juis oor die wese van God en sy verhouding tot die wêreld, oor die roem van God en die troos van sy kinders (Abma \& De Bruijn 1989:106).

Baie van Hoedemaker se tydgenote het 'n lou houding teen die historiese kritiek ingeneem. Hulle het dit nie skerp afgewys nie, maar het ook nie diep daarop ingegaan nie. Met Hoedemaker was dit anders. 'Hoewel het in directe zin zijn vak niet was, heeft hij duizenden bladzijden van gerenommeerde kritische geleerden in de Bijbel wetenschap conciëntieus doorgeploegd' (Abma \& De Bruijn 1989:107).

Die gefassineerdheid wat baie Bybelgeleerdes in sy tyd ervaar het as gevolg van hulle literêre en historiese ontdekkingstog, kon Hoedemaker nie deel nie. Daarin het hy ook skerp verskil van J H Gunning (jr) uit die kringe van die etiese rigting. Gunning het positiewe waardering betoon vir wat deur moderne ondersoek histories-krities oor die Skrif op die tafel geplaas is.

Hoedemaker skryf en leef vanuit die stralende sekerheid: die waarheid van die Heilige Skrif. Tot die mate waarin die Mosaïese oorsprong die Goddelike oorsprong van die Skrif in gedrang bring, is dit selfs wel van belang. Dat hy met sy opvattinge reeds in sy tyd totaal verouderd was, het Hoedemaker nie ingesien nie, of dit het hom weinig aangegaan. Die twintigste eeu sou 'n verdere ontploffing van literêre, historiese en argeologiese fondse van buite die Bybel bring wat lig op Bybelgedeeltes werp. Die enorme betekenis daarvan word vandag op geen wyse ontken nie.

Wat vir ons in Hoedemaker selfs vandag steeds belangrik is, is die skerp wyse waarop hy raakgesien en geformuleer het dat in die Bybelwetenskap van sy tyd, soos ook dikwels daarna, die historiese as kritiese instansie ingespan word om die Bybel te verstaan. Daarmee word 'n norm vir Skrifverstaan van buite ingevoer wat die Bybel self nie so ken of gebruik nie (Abma \& De Bruijn 1989:109).

Uitsprake van Hoedemaker soos dat die ware wetenskap Christosentries is, asook sy kompromisloosheid ten opsigte van die Mosaïese oorsprong van die eerste Bybelboeke, kan die indruk laat dat hy erg fundamentalisties was in sy omgang met die Bybel.

Dit is egter nie die geval nie. Die meganiese inspirasie van die Skrif is deur hom verwerp. Die wetenskap wat die Bybel uitlè, moet rekening kan hou met die unieke karakter van die Bybel. Die Bybelskrywers is nie as willose werktuie behandel en ingespan nie, maar as persoonlike redelike wesens. Daarom moet teoloë ook 
in hulle uitleg van die Bybel hulle gesonde verstand gebruik. Die rede moet egter as instrument en nie as bron gebruik word nie.

Die vraag wat in die tyd so dikwels in die diskussie rondom die verstaan en uitleg van die Bybel gestel is, was: In welke mate mag die uitleg van die Bybel bepaal word deur die geloof in die Bybel self? Hoedemaker het nooit ontken dat die moderne navorsing belangrike gegewens met die oog op die verstaan van die Bybel versamel het nie, maar die wetenskap is aan sy objek gebonde. Wie oor God en Christus wil praat sonder kennis van God en Christus, beoefen nie wetenskap nie.

Die wetenskap is nie neutraal nie. Die historiese kritiek is ook nie neutraal nie. Want dit gaan uit van die evolusieteorie en dié teorie is, konkreet toegepas, 'n verloëning van God.

Volgens Wellhausen en Kuenen is daar 'n geleidelike ontwikkeling in die godsdiens van Israel sigbaar. Die eerste en mees primitiewe stadium kom na vore in die tyd van die Rigters. Die wet volg baie later. Dié ontwikkeling wys Hoedemaker af. Die wet, die volmaakte, staan aan die begin. Die tyd van die Rigters was 'n tyd van diepe verval. In die strominge van sy tyd merk Hoedemaker ou dwalinge onder 'n nuwe naam. Die Skrifkritiek se wortels lei hy terug na teologiese opvattinge met valse filosofiese uitgangspunte: Cartesianisme, verwaterde supranaturalisme, verkapte remonstrantisme, naturalisme (Abma \& De Bruijn 1989:120). Teenoor die wetenskap wat só van foutiewe filosofiese uitgangspunte uitgaan, stel Hoedemaker 'n gelowige wetenskap. Neutrale wetenskap bestaan nie. 'Zoolang de nieuwe Schriftkritiek haar beginsel, hare methode van onderzoek niet heeft gelegitimeerd, ontzeggen wij haar alle wetenschappelijk karakter' (in Abma \& De Bruijn 1989: 125).

Hoedemaker laat geen onduidelikheid oor waarom die Mosaïese oorsprong van die Pentateug vir hom so van uiterste belang is nie. Hy verduidelik dit byvoorbeeld na aanleiding van die datering van die boek Deuteronomium. Volgens die Bybel se eie gegewens is die boek van Moses afkomstig. In die negentiende eeu het baie navorsers egter begin om dit in die tyd van koning Josia, dus teen die sewende eeu voor Christus te plaas.

Hoedemaker reageer hierop besonder fel. Tydens die versoeking van Jesus in die woestyn, antwoord Hy die satan met aanhalings uit Deuteronomium. As die boek nou 'n wet uit later eeue verteenwoordig, beteken dit dat dié woorde valslik vir Jesus in die mond gelê word. Dít, sê Hoedemaker, noem hy misleiding. Jesus Christus is die vervulling van die hele Ou Testament. Daarom is Hy ook die sleutel tot die verstaan daarvan. Die Ou Testament is onmisbaar vir die verstaan en kennis van Jesus Christus se persoon en werk. 
Die menslike faktor in die totstandkoming van die Skrif het Hoedemaker nooit ontken of onderskat nie. Dit is waar dat die verskillende outeurs die waarheid uit verskillende hoeke bekyk, vandaar die wye verskeidenheid en oorsprong, karakter en vorm wat ons in die Bybel aantref; ook die verskeidenheid in literaturgenres. Die Bybel is nie deur een man uit een tydperk van die geskiedenis geskryf nie. Met dié verskeidenheid moet in die uitleg rekening gehou word. Daarom was dit Hoedemaker se geliefde metode om Skrif met Skrif te vergelyk. Daartoe het sy enorme kennis van die Bybel en veral die Ou Testament hom gehelp.

Dié verskeidenheid mag egter nie beteken dat die eenheid van die Skrif ontken word nie. Sy metode om Skrif met Skrif te vergelyk, 'is gebaseerd op het gronddenkbeeld, dat voor hem steeds als een geloofsapriori vaststond, dat de Schrift van goddelijken oorsprong, en daarom door hoevele menschelijke outeurs, in hoevele onderscheidene tijden, uit hoevelerlei oogpunt ook geschreven, één is' (in Abma \& De Bruijn 1989:141). Die eenheid van die Skrif is vir hom die kragtigste getuienis aangaande die betroubaarheid daarvan. Die Skrif is een organiese geheel wat basies deur een gedagte beheers word.

$\mathrm{Al}$ is dit só dat baie van Hoedemaker se konsepte oor Skrif, openbaring en geskiedenis verouder is, bly deeglike kennisname van sy teologie prikkelend en rigtinggewend. In sy afweer teen die historiese kritiek het hy seker soms te ver gegaan. Maar waarvoor hy met groot hartstog gestry het, mag die kerk nooit kwytraak nie: dat God tot ons heil in die tyd en geskiedenis spreek en ingryp. Teenoor die naturalisme van sy tyd wat geleer het dat daar nie lynreg tot wonderbaarlike ingrype van God gekonkludeer moet word nie, het Hoedemaker vasgehou aan die wonders wat God doen.

Met sy siening van 'n organiese, liewer as meganiese inspirasie van die Skrif, het hy na aan sowel Kuyper as Bavinck gekom teenoor die sewentiende- en agtiendeeeuse ortodokse sieninge. By dié opvattings het Hoedemaker gebly, ook nadat hy oor ander sake radikaal met Kuyper tydens die Doleansie gebreek het. Ook daaruit blyk sy integriteit en selfstandigheid.

Diepte, breedte, omvattendheid kenmerk Hoedemaker se teologie. 'n Naprater was hy nooit. Cliche's het hy nie geken nie, ook nie oppervlakkigheid nie. Die foute en dwalinge van die historiese kritiek het hy nie op geïsoleerde basis bestry nie. Hy het dit weerle in 'n breed uitgewerkte selfstandige teologie. Maar dít het hy gedoen eers nadat hy hom baie diep in die historiese kritiek ingegrawe het en die wysgerige en teologiese agtergronde daarvan blootgele het.

Van Hoedemaker se belangrikste boeke, brosjures en ander publikasies uit hierdie tyd en oor hierdie onderwerp was: Zonde en genade: de tijd der Richteren; De Mozaïese oorsprong van de wetten in de boeken Exodus, Leviticus en Numeri: Lezingen 
over de moderne Schriftcritiek des Ouden Testaments; Zonde en genade; Genade en Recht: Israel onder de regering van Saul en Dawid, Christus voor de rechtbank der modeme wetenschap; Handboek voor het ondenwijs in het Oude Testament; Handboek van het Nieuwe Testament; Het evangelie in het Oude Verbond.

In die geskrifte het hy stryd gevoer met Wellhausen en Kuenen, met Gunning en Valeton, met Hengstenberg en Delitzsch, met Doedes, Van Oosterzee en Wildeboer. Dat dit wesenlik gegaan het om 'n stryd tussen geloof en wetenskap, het hy verwerp. Dit gaan om 'n stryd tussen wetenskap en wetenskap!

\section{HOEDEMAKER EN DIE GODSDIENSTIGE OPVOEDING VAN DIE JEUG}

Uit heelwat van sy werk en geskrifte blyk dat Hoedemaker baie belangstelling gehad het in vrae rondom die geloofsopvoeding van die jeug. Die groot gesin wat hy en sy vrou ontvang het, het hom geleentheid gebied om hom intens in die oordra van die Bybelse inhoud aan die kind te verdiep en te oefen.

Sy basiese benadering was dat daar nie by kinders so sterk aangedring moet word op bekering en wedergeboorte nie, maar liewer op die vorming van Christelike karakters. Die kind moet van kleins af gewoond gemaak word aan orde en tug. Die kind moet leer om sy wil te buig onder dié van 'n ander en om uit liefde te gehoorsaam.

Dit beteken nie dat Hoedemaker die noodsaak van bekering en sondebesef afgewater het nie. Maar hy wil beklemtoon dat daar nie van die bekering verwag moet word wat die geloofsopvoeding eintlik moes bewerk nie: 'n weltoebereide aarde waarin die saad van die evangelie kan val.

Self het hy oor goeie gawes van die vertelkuns beskik en het daarom graag by die kinderkerk-geleenthede in Amsterdam voorgegaan. In sy jong jare in Amerika raak hy reeds betrokke by kinderevangelisasie. Terug in Nederland word hy die eerste sekretaris van die Nederlandse Sondagskoolvereniging en ook redakteur van De Familiekring, maandblad om die Sondagskoolpersoneel toe te rus.

Selfs tot in sy Sondagskoolwerk behou Hoedemaker sy omvattende benadering, sy visie op die heelheid van kerk en volk. Hy verwerp 'n eensydige intellektualistiese of piëtistiese benadering en bepleit ' $n$ integrale benadering van die kind in sy leefwêreld. Ook die metodisme werkt te individualistisch, denkt alleen aan de ziel en haalt de enkeling weg uit zijn verbanden. Maar men moet de geheele natie op het oog hebben' (Abma \& De Bruijn 1989:160).

Sy belangstelling in jeug- en Sondagskoolwerk het Hoedemaker sy lewe lank behou. Ook toe die kerkkwessie en sy stryd met Kuyper hom later voltyds in beslag 
neem, begin hy as redakteur van die weekblad De Gereformeerde Kerk in 1895 met 'n rubriek vir die Sondagskool.

Ook met die kategese het Hoedemaker hom intens bemoei. Vir sowel die gewone as die belydeniskategese stel hy handleidings op: De Bijbelsche geschiedenis voor catechisatiën en scholen en Een eenvoudige onderwijzing in de christelijke leer naar de belijdenis der Hervormde Kerk.

Met ' $n$ reglementwysiging in 1880 is die invloed van ouderlinge by die aanneming van nuwe lidmate so te sê uitgeskakel. Vrysinnige predikante met modernistiese opvattings het 'n vry hand gehad om te katkiseer en aan te neem. Dit verklaar waarom die attestenkwestie tot die Doleansie kon lei.

Saam met Kuyper verset Hoedemaker hom teen dié onhoudbare situasie. As hy in $\mathbf{1 8 7 5}$ in Rotterdam preek voor 'n groot groep aannemelinge, sê hy dat hy dit nie in feestoon kan doen nie. Hy vermoed dat vele nie onderrig is in die Bybelse leer nie en beskouings huldig wat in stryd is met die Gereformeerde, selfs die Christelike belydenis.

Maar - en weer 'n keer kom Hoedemaker se kerklike verbondsdenke wat hom telkens weer in botsing met Kuyper bring sterk na vore - hy gaan voort, want die nuwe verbond is immers gegrond in wat Christus volbring het en nie in goeie menslike voornemens nie (Abma \& De Bruijn 1989:162).

Vir die godsdiensonderrig op skool skryf Hoedemaker sy Handboek voor het godsdienstonderwijs.

In sekere opsig is dit merkwaardig dat Hoedemaker op onderwysgebied nie so rigied teen afskeiding was as op kerklike gebied nie. Oprigting en instandhouding van skole moet aan privaatinisiatief oorgelaat word. Slegs waar dit nie gebeur nie, moet die owerheid self skole oprig. In dié skole moet die Christelike element in die onderwys gewaarborg word.

En juis op dié punt ontwikkel Hoedemaker ernstige beswaar. In soverre daar in die openbare skool van sy tyd nog van godsdiensonderrig sprake was, was dit onder invloed van die moderne teologie. Hy vind dit verkeerd dat baie hulle tevrede stel met 'n vrye Christelike skool, terwyl die openbare onderwys onchristelik is. Weer eens is sy belangrikste motief sy bewoënheid met die geheel van die samelewing. 'Een Gereformeerd volk geeft zijne Kerk niet prijs, om daarbuiten een afdak op te slaan, waar het voor wind en weder geborgen is. Heel de Kerk en heel het volk' (Abma \& De Bruijn 1989: 166).

Op akademiese terrein het Hoedemaker hom sterk beywer vir die herstel van die teologiese fakulteite. Hy verset hom teen die Hoër Onderwyswet van 1876 wat die duplex ordo in die teologiese fakulteite ingevoer het. Van die openbare univer- 
siteit mag nie weerhou word wat aan die besondere universiteit gegun word nie: 'n simplex ordo.

Dat de openbare theologische faculteit een Hervormd karakter dragen moest, lag in de oorsprong van onze natie, in haar geschiedenis, alsmede in overwegingen aan de practijk en het belang der universiteiten ontleend, en deed niets te kort aan de eis der onpartijdigheid.

(Balke 1989:7)

\section{HOEDEMAKER OOR DIE STAAT, NEUTRALITEIT, TEOKRASIE EN ARTIKEL 36 VAN DIE NEDERLANDSE GELOOFSBELYDENIS}

Hoedemaker en Kuyper het oor 'n saak soos die verstaan en uitleg van die Heilige Skrif nooit ernstig van mekaar verskil nie en het soms selfs baie na aan mekaar beweeg. Hulle was ook een in hulle verwerping van die kerklike bestuurstelsel en reglementebundel van 1816, hoewel hulle spoedig hewig verskil het oor hoe dié probleem hanteer en opgelos moes word. Kuyper kies uiteindelik vir kerkskeuring. Hoedemaker wil ten alle koste die eenheid en heelheid van die kerk behou. Mettertyd het al duideliker geblyk dat dit nie maar net 'n vraag was oor hoe die dwaling van 1816 reggestel moes word nie, maar dat daar prinsipieel 'n onoorbrugbare kloof in kerkbeskouing tussen hulle was (Van Wyk 1990:507).

Naas die kerkbeskouing is ook aangetoon dat daar ernstige meningverskil tussen Kuyper en Hoedemaker ontstaan het oor die funksie van die Vrije Universiteit. Die wyse waarop Kuyper die Vrije Universiteit in diens van die Doleansie gebruik het, was die direkte oorsaak dat Hoedemaker sy ontslag as hoogleraar aan dié inrigting aangevra het.

Toe die afskeiding van Kuyper en sy geesgenote 'n voldonge feit was en Kuyper hom tot die aktiewe politiek wend, het 'n ewe hewige konflik tussen hom en Hoedemaker gevolg rondom die sake soos dit in die opskrif hierbo aangedui is.

'n Saak waarmee Hoedemaker hom skerp gekonfronteer gevoel het, was die fenomeen van die neutrale staat, ' $n$ konsep wat volgens hom geen steun in die Bybel vind nie. Van mekaar losgeskeur, sou nòg die kerk nòg die staat sy opgelegde taak kon vervul.

Ook op dié terrein verskyn van Hoedemaker publikasies wat groot invloed in sy tyd uitgeoefen het: Antikel XXXVI onzer Nederduitsche Geloofsbelijdenis tegenover dr A Kuyper gehandhaafde; Nog rechts noch links, maar den koninklijken weg; Het eerstgeboorterecht voor een schotel moes?

Die staat moet ook in sy instellinge sy wesenskenmerk as staat-met-die-Bybel laat sien. 
Abma \& De Bruin (1989:189) skets iets van die agtergrond van waaruit ook Hoedemaker in hierdie tyd van politieke hoogspanning met Kuyper bots:

Vele liberalen gruwden bovendien van Kuypers antitheseleer en -politiek die naar hun gevoelen Nederland volgens de scheidslijn van vór of tegen de confessionele partij, vooral vóor of tegen die van Kuyper, verdeelde in christen en niet-christen. Kuyper trok alles naar zijn, onmiskenbaar, formidabele persoonlijkheid toe en toonde geen oog te hebben voor de eenheid van de natie en het nationale belang dat elk kabinet, dus, ook het zijne, diende te behartigen. Te denken valt hierbij aan de polarisatie-strategie van de Partij van de Arbeid in de jaren '70 van deze eeuw. Hoe zeer tegengesteld verder ook, liberaal en socialist waren het nu eens: tegen Kuyper en zijn kabinet. Maar ook voelden christenen van andere confessionele partijen ernstige bezwaren tegen Kuypers autoritaire optreden, zijn antitheseleer en weinig openstaan voor denkbeelden van anderen die minder dan zijn volgelingen overtuigd waren van het succes van het kabinet-Kuyper. Ook en vooral als men de daden toetste aan de beginselen waarvan het pretendeerde uit te gaan.

Kuyper se konsep van die neutrale staat het Hoedemaker se gramskap opgewek. Die stryd daarteen sou vir die laaste twintig jaar van sy lewe bykans al sy kragte in beslag neem. Met dié konsep het hy geglo dat Kuyper en sy Anti-revolusionêre Party en Gereformeerde Kerke die geskiedenis en godsdienstige tradisie van Nederland vir 'n pot lensiesop verkwansel.

Die hoogtepunt van Hoedemaker se verset teen Kuyper se staatsopvatting kom tot uiting in die diskussie rondom Artikel 36 van die Nederlandse Geloofsbelydenis. Met sy antiteseleer gee Kuyper die eenheid van die volk prys; die evangelie word van die skare van onwetendes aan die neutrale skool weerhou; laasgenoemdes word selfs aan die oordeel en verlorenheid prysgegee.

Hoe, vra hy aan Kuyper, moet die owerheid hom vir die koninkryk van Christus beywer as hy hom ook neutraal moet hou? Moet die owerheid die koninkryk bevoordeel deur hom nie daarmee te bemoei nie? Hoedemaker was oortuig dat Kuyper die Dogmatiek en Kerkreg in diens stel van sy politieke ideale. Kuyper gaan met Bybelse kernwoorde om, nie asof hy hulle uit die Bybel haal nie, maar uit 'n woordeboek. Kuyper dink onsamehangend, maar verberg dit agter groot woorde!

Teokrasie, sê Hoedemaker, is Godsregering. Dit wil sê: God oefen self die gesag uit. Hy doen dit deur die owerheid. Daarom is die owerheid aan Hom alleen verantwoording verskuldig. God gryp nie net nou en dan in, maar laat sake verder aan die mens oor nie. Teokrasie beteken dat God woning maak onder die mense. 
Hy doen dit deur die orgaan wat Hy daarvoor verkies het: die kerk. Dit is die kerk van die Reformasie, in dié geval die Nederlandse Hervormde Kerk.

Kerk en staat moet ingerig word aan die hand van Artikel 36 van die Nederlandse Geloofsbelydenis. Die owerheid regeer deur die guns van God en is alleen aan God verantwoording verskuldig. ' $n$ Belangrike rol word toegeken aan die openbare uitleg van die kerk, vir Hoedemaker steeds die Nederlandse Hervormde Kerk. Hy het altyd moeite gehad met die Grondwet van 1848 waarvolgens die Nederlandse Hervormde Kerk 'n kerkgenootskap is gelyk aan alle ander kerkgenootskappe.

Kuyper se opvattings kom vir hom daarop neer dat die staat geen eie godsdienstige beginsel kon handhaaf as rigsnoer vir wetgewing en regeringsbeleid nie. Die staat staan buite en bo elke kerk, elke geloofsoortuiging. Die staat mag geen eie oordeel hê nie, hy mag geen uitdrukking van die nasionale lewe wees nie. Die staat mag geen bande met die Nederlandse Hervormde Kerk hê nie, hy mag nie die ware godsdiens bevorder en ook nie die valse godsdiens weer nie.

Hoedemaker hou aan pleit vir 'n staat met die Bybel. Die Nederlandse nasie is 'n Protestantse nasie. Die Protestantse karakter kom tot uitdrukking in die Nederlandse Hervormde Kerk in gereorganiseerde vorm, dus waarheen die afgeskeidenes sal terugkeer. Die eis om Christelik-protestantse volk te wees, geld nie net vir die Nederlandse volk nie, maar vir elke volk.

Hoedemaker is ongetwijfeld de belangrijkste theokratische denker in de vorige eeuw geweest. De diepste tendenzen van Calvyn komen bij hem opnieuw tevoorschijn...Vandaar het vasthouden aan de onverkorte tekst van Artikel 36, want daarmee word geen staatskerk bedoeld, noch een aan de kerk gehouden staat, maar wel een staat met de Bijbel.

(Balke 1985:63)

\section{SAMEVATTENDE OPMERKINGS}

Daar is in die voorafgaande bladsye telkens die indruk uitgespreek dat $\mathbf{P} \mathbf{J}$ Hoedemaker 'n boeiende, oorspronklike figuur moes gewees het. Dat hy terselfdertyd 'n moeilike medewerker en nog moeiliker teenstander moes gewees het, is ook duidelik. 'n Mens lees trouens van geen mens of rigting met wie Hoedemaker werklik van harte en volledig saamgegaan of meegewerk het nie.

Die feit dat hy steeds imponeer, hang met 'n paar dinge saam. Hy het 'n enorme kennis van die Bybel gehad. Sy nalatenskap skerp dit steeds by ons op om eers die Bybel te lees en te ken voordat daar begin word met die studie van teologiese werke. Hy was 'n veelsydige teoloog wat probleme nie geïsoleerd beskou het nie, maar altyd vanuit wye agtergronde en samehange. 
Tydgenote en studente maak egter ook melding van negatiewe fasette rondom sy persoon. Hy het soms die indruk gelaat van 'n weifelende, onbesliste mens wat meermaal vroeëre uitsprake moes korrigeer of herroep. Dit is waarskynlik veroorsaak deur 'n impulsiewe geaardheid wat daartoe gelei het dat hy sake eensydig en oorhaastig kon beklemtoon. Daar was ook by hom die neiging om 'n saak wat hom aangegryp het, te pak, vinnig te deurworstel, 'n brosjure of twee daaroor die lig te laat sien en daarna belangstelling te verloor; vandaar die groot getal brosjures wat uit sy pen gevloei het, maar ook 'n klomp onvoltooide werke van wyer formaat.

Dat sy skryfwerk nie altyd maklik verstaan kan word nie, hang saam met sy liefde om eindelose feite en agtergrondmateriaal in sy werk in te vleg; ook met die antitetiese wyse waarop hy in voortdurende diskussie of konflik met opponente sy eie konsepte ontwikkel het.

Dat Hoedemaker se wetenskapsbeskouing, sy houding teenoor baie resultate van die historiese kritiek en baie aspekte van sy staatsbeskouing deels onprakties, deels verouder is, of net eenvoudig nie meer as haalbaar beskou word nie, is reeds toegegee.

In die Nederlandse Kerk en staatkunde het sake anders geloop as wat Hoedemaker dit wou hê. Hy wou ten alle koste die rigtingstryd in die Nederlandse Hervormde Kerk beëindig; so ook die neutrale owerheid. Reeds in 1906, nog tydens Hoedemaker se lewe, neem die rigtingstryd in die Nederlandse Hervormde Kerk toe met die stigting van die Gereformeerde Bond. Op politieke terrein was die beweging net aanhoudend al verder weg van Hoedemaker se teokratiese ideaal af.

Uiteindelik is die beslissende vraag natuurlik nie of ' $n$ man se teologie prakties, suksesvol of haalbaar is nie. Die vraag is of dit waar is, of dit in lyn staan met die Bybel. As dit so is, behoort daar groter terughoudendheid te wees as om Hoedemaker se standpunte oor genoemde saak sommer as irrelevant af te maak.

Hoedemaker se grootste nalatenskap aan ons bly waarskynlik sy hartstogtelike liefde vir die kerk; sy oortuiging om, ondanks alle gebreke in die kerk te bly; dat daar ook vir die 'skare' plek in die kerk moet bly; maar ook sy kompromislose verset teen alle groep- en partyvorming in die kerk. Ons laat daaroor verder 'n hedendaagse Nederlander aan die woord:

Zijn staats- en wetenschaps-opvatting achten wij misschien nu niet meer verdedigbaar. Niettemin gaat er achter zijn 'voorgronds-strijd' een hartstocht schuil die een nadere beschouwing waard is. Het is de hartstocht van de verdediging van een principiële historische samenhang tegenover fragmentarisering en reduktie. De reduktie van kerk tot kerkgenootschap, de reduktie van volk tot toevallige geografische opeenhoping van mensen, de reduktie van belijdenis tot partijleus, de 
reduktie van schriftuurlijk overheidsgezag tot politieke stuurmanskunst, de reduktie van het gevecht om de waarheid tot strijd tussen partijen - dat alles zag Hoedemaker als een gevolg van de revolutie, van het 'moderne' neutraliteits-beginsel; en hij zag daarin een vlucht voor de probleemstelling van de eigen geschiedenis en een verraad van de verworvenheden van de Reformatie.

(Abma \& De Bruijn 1989: 261)

Hoedemaker het baie geweifel. Maar dit was 'n weifeling wat gebore is uit die hartseer oor die konflik met 'n man wat hy sy lewe lank graag as bondgenoot wou hê: Abraham Kuyper. Toe hy uiteindelik die aarseling oorwin het, was hy onbuigsaam in sy eie offensief, maar nie sonder hartseer oor die verdeeldheid en skeiding nie.

Er valt geen aarzeling meer te bespeuren of discussiëren vanuit de verdediging; hij toont zich in staat tot het offensief over te gaan. Ofschoon de lange aarzeling maar al te begrijpelik was, want hoe men het ook wendt of keert, zijn strijd met Kuyper was en bleef voor hem een broederstrijd. Daarom niet minder strijd, maar juist des te heftiger en tragischer, in elk geval voor Hoedemaker. Kuyper genoot in zijn kerken en partij, in theologie en politiek, zoveel macht en aanzien, voelde zich so zelfverzekerd en overtuigd van het eigen gelijk dat besef van het tragische bij hem nauwelijks te bespeuren valt. Hoedemaker daarentegen, evenals Groen 'politicus niet, evangeliebelijder', achtte zich door Kuyper triomfantelijk doodgezwegen en beschouwde deze als een vanwege zijn successen tot een door en door profaan politicus verworden figuur, verloochenend de principiële beginselen waarover zij het in wezen eens hadden moeten zijn en die hen wederzijds hadden moeten binden en verbinden.

(Abma \& De Bruyn 1989:20)

\section{Literatuurverwysings}

Abma, G \& De Bruijn, J (reds) 1989. Hoedemaker herdacht. Ten Have: Baarn.

Balke, W 1985. Gunning en Hoedemaker: Samen op weg. S-Gravenhage: Boekencentrum.

Balke, W 1989. De theologische betekenis van Hoedemaker. Ongepubliseerde lesing gehou tydens Hoedemakerherdenking aan die Vrije Universiteit, 27 Oktober 1989 .

Scheers, G Ph 1939. Philippus Jacobus Hoedemaker. Wageningen.

Van Wyk, D J C 1990. P J Hoedemaker: Wat ék bedoel, is die behoud van die kerk. HTS 46, 497-512. 